\title{
LOCAL VIBRATION INFLUENCE OF ELECTROMYOGRAPHY PARAMETERS ON ANAEROBIC CAPACITY TEST IN ROWERS
}

\author{
Kalvis Ciekurs \\ Latvian Academy of Sport Education, Latvia \\ Viesturs Krauksts \\ Latvian Academy of Sport Education, Latvia \\ Daina Krauksta \\ Latvian Academy of Sport Education, Latvia \\ Juris Grants \\ Latvian Academy of Sport Education, Latvia \\ Žermēna Vazne \\ Latvian Academy of Sport Education, Latvia
}

\begin{abstract}
Whole body vibration is a worldwide innovation as a part of training method that helps athletes to regain the power and get ready for next training faster. However less attention is paid to local vibration where an isolated muscle or muscle group is stimulated by the use of a vibration device. For the reason to determine the effect of local vibration on anaerobic capacity of rowers, two research groups were assembled from the students of Murjanni Sport Gymnasium (MSG). The following methods were used in the study: tests - Concept-2, local vibration (LV) manipulations, electromyography and mathematical statistics. The electromyography was made with Biometric LTD. LV manipulations were done to the muscles erector spinae, latisimus dorsi, teres major, teres minor, trapezius, infraspinatus, deltoideus, slenius capitis, triceps brachii, gluteus maximus, semitendinosus, biceps femoris, semimembranosus, castrocnemius, tendo calcaneus, rectus femoris, vastus lateralis, tensor fascia latae, vastus medialis, sarterius, ligamentum patellae, tibialis anterior, rectus abdominis, pectoralis major un biceps brachii. We using $100 \mathrm{~Hz}$ frequency, 2 - $4 \mathrm{~mm}$ amplitude and different pressure on the muscles. The total LV application time was 5 to $20 \mathrm{~min}$. The obtained data were processed using mathematical statistics. The results: having stated the result difference before $L V$ and after it. The results testify significant improvement of Concept2 tests results and electromyography results, what is showed by the difference of the mean results. Comparing the results of the rowers of experimental group (EG) and control group (CG) they have differences in the left side muscle latissimus dorsi after the t-test where $p>0.05$, but stating the percentage of the mean result difference of this muscle it was found out that $p>0.05$ what also shows significant changes in the muscle biopotential $(\mathrm{mV})$.
\end{abstract}

Keywords: anaerobic capacity, rowers, local vibration, electromyography. 
Ciekurs et al., 2020. Local Vibration Influence of Electromyography Parameters on Anaerobic Capacity Test in Rowers

\section{Introduction}

In rowing, as in any sport, dominant physical abilities, necessary for the definite sport, are emphasized. In rowing the basic physical abilities are endurance and strength. It is much spoken about and researched how to increase the speed of moving in rowing. As one of the ways how to solve the problem local vibration application before and after competitions, as well as during training sessions, is offered (Siegmund, Barklty, Knapp, \& Peer, 2014). Many scientists as Hofmijster (2010), Hawkins (2000) and others have researched the possibilities of increasing the speed of moving in rowing. Most part of researches is based on oxygen maximal consumption and other physiological changes during a load. Although there are various researches, stating the technical nuances of leg and arm work, comparatively little attention is paid to the role of the arm work.

The cycle length in different distances and having different water flow before the wind, against the wind and with the side wind is stated. The attempts to combine vibration loads with traditional strength trainings with the purpose to achieve greater increase of the work capacity of the neuro-muscular system than only using classical strength trainings have already been carried out comparatively long ago (Souron et al., 2019; Souron, Besson, Lapole, \& Millet, 2018; de Paula, Moreira, \& Szmuchrowski, 2016). Recent research gives notion about the fact that vibration trainings both in acute or chronic form have explicitly positive effect on strength and power expressions in athlete whole preparation process. It is considered that it is possible to excellently observe muscle biopotential $(\mathrm{mV})$ at different loads by the electromyograph, as well as to observe muscle fatigue after loads (Knipše, 2009). To state the training process and its usefulness for top rowers it is necessary to state muscle biopotential $(\mathrm{mV})$ and frequency $(\mathrm{Hz})$ during a stroke and relaxation what is essential precondition for renewal between the strokes (Schaar \& Mattes, 2010; Nowicky, Burdett, \& Horne, 2005). The epidermal electrodes were used in the research which registered muscle biopotential $(\mathrm{mV})$ and frequency $(\mathrm{Hz})$.

\section{Methodology}

To state the effectiveness of the local vibration on rowers' muscles biopetentials the experimental group (EG) and the control group (CG) were form including the students of Murjani Sport Gymnasium (MSG). MSG students were chosen because they all train according to the similar system, as well as their daily routine is similar, too. 15 MSG students were chosen in the experimental group and 12 MSG students in the control group, their age was $18-24$, on average $19.6 \pm 1.45$ years (EG) and $19.3 \pm 1.72$ years (CG), having different experience in rowing. The height of the participants of EG was on average $190.7 \pm 3.4 \mathrm{~cm}$, 
but of CG $189.0 \pm 2.7 \mathrm{~cm}$, but the weight of the participants of EG was on average $88.0 \pm 5.0 \mathrm{~kg}$ and of CG it was $88.3 \pm 3.4 \mathrm{~kg}$. The average age of the groups was $19.5 \pm 1.6$, the average height $190.0 \pm 3.2 \mathrm{~cm}$, but the average weight $88.1 \pm 4.3$ $\mathrm{kg}$. Performing of the first test on the stationary ergometer Concept-2 and additionally stating of electromyography (EMG) before and after LV (figure 1).

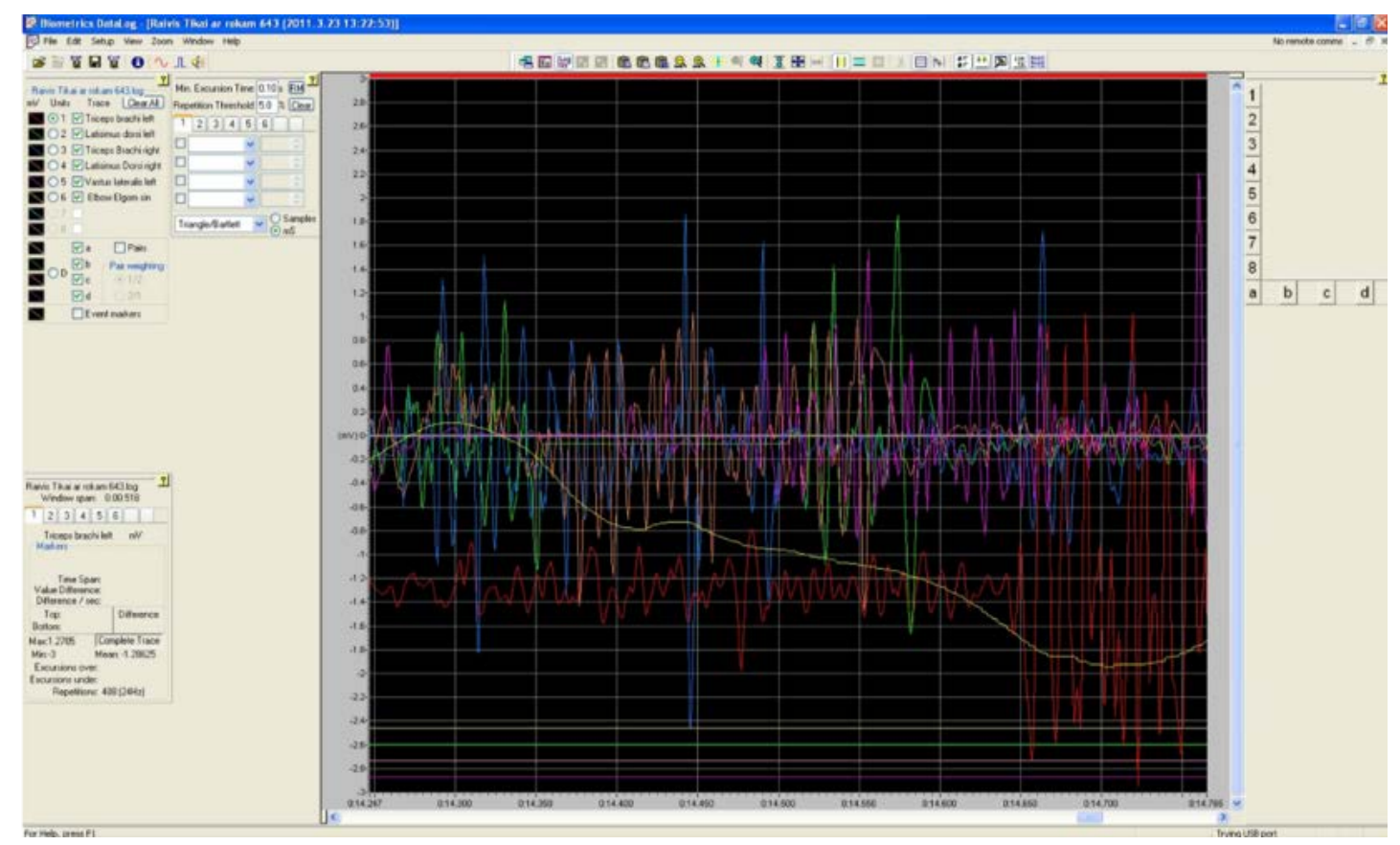

Figure 1 Electromyography in anaerobic power capacity test - one stroke

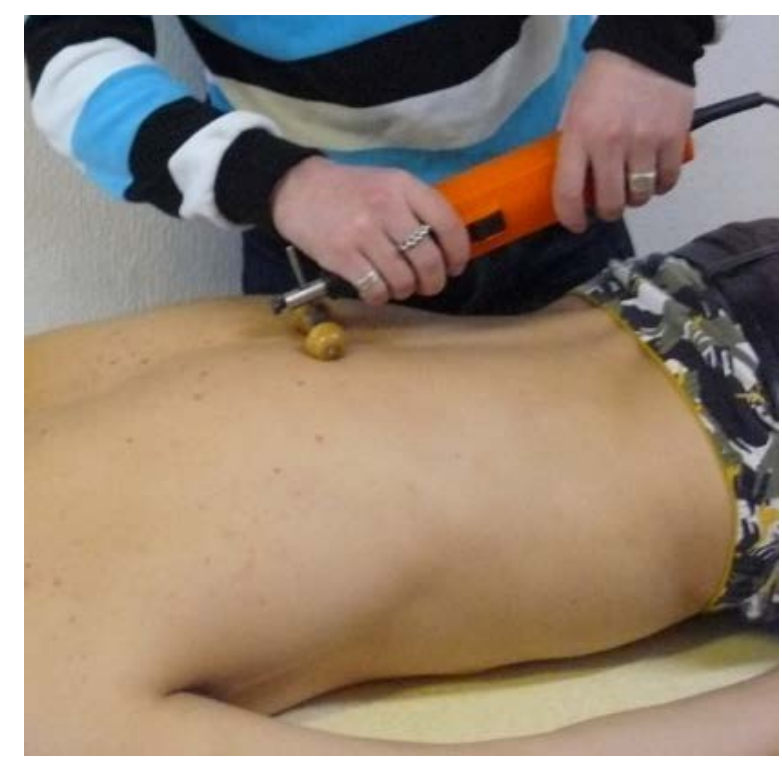

Figure 2 Local vibration training for the muscle erector spinae (vibro-equipment - VIBROMED) 
Ciekurs et al., 2020. Local Vibration Influence of Electromyography Parameters on Anaerobic Capacity Test in Rowers

The methodology of local vibration trainings (figure 2) was developed for the following muscles: erector spinae, latisimus dorsi, teres major, teres minor, trapezius, infraspinatus, deltoideus, slenius capitis, triceps brachii, gluteus maximus, semitendinosus, biceps femoris, semimembranosus, castrocnemius, tendo calcaneus, rectus femoris, vastus lateralis, tensor fascia latae, vastus medialis, sarterius, ligamentum patellae, tibialis anterior, rectus abdominis, pectoralis major un biceps brachii.

The trainings of local vibration to the whole body applied on the experimental group participants were held. The sessions of local vibration (Table 1) were held according to the methodology developed together with Prof. V. Krauksts.

Table 1 Scheme of local vibration for Murjani Gymnasium athletes

\begin{tabular}{|c|c|c|c|c|}
\hline Week & $\begin{array}{c}\text { Vibration } \\
\text { frequency }\end{array}$ & $\begin{array}{c}\text { Vibration } \\
\text { amplitude }\end{array}$ & $\begin{array}{c}\text { Vibration length } \\
\text { in minutes }\end{array}$ & $\begin{array}{c}\text { Vibration times } \\
\text { a week }\end{array}$ \\
\hline Week 1 & $100 \mathrm{~Hz}$ & $2 \mathrm{~mm}$ & $5 \mathrm{~min}$ & 2 \\
\hline Week 2 & $100 \mathrm{~Hz}$ & $2 \mathrm{~mm}$ & $5 \mathrm{~min}$ & 3 \\
\hline Week 3 & $100 \mathrm{~Hz}$ & $2 \mathrm{~mm}$ & $10 \mathrm{~min}$ & 2 \\
\hline Week 4 & $100 \mathrm{~Hz}$ & $2 \mathrm{~mm}$ & $10 \mathrm{~min}$ & 3 \\
\hline Week 5 & $100 \mathrm{~Hz}$ & $4 \mathrm{~mm}$ & $12 \mathrm{~min}$ & 2 \\
\hline Week 6 & $100 \mathrm{~Hz}$ & $4 \mathrm{~mm}$ & $12 \mathrm{~min}$ & 3 \\
\hline Week 7 & $100 \mathrm{~Hz}$ & $4 \mathrm{~mm}$ & $15 \mathrm{~min}$ & 2 \\
\hline Week 8 & $100 \mathrm{~Hz}$ & $4 \mathrm{~mm}$ & $15 \mathrm{~min}$ & 3 \\
\hline Week 9 & $100 \mathrm{~Hz}$ & $4 \mathrm{~mm}$ & $20 \mathrm{~min}$ & 2 \\
\hline Week 10 & $100 \mathrm{~Hz}$ & $4 \mathrm{~mm}$ & $20 \mathrm{~min}$ & 3 \\
\hline Week 11 & $100 \mathrm{~Hz}$ & $4 \mathrm{~mm}$ & $15 \mathrm{~min}$ & 3 \\
\hline Week 12 & $100 \mathrm{~Hz}$ & $4 \mathrm{~mm}$ & $15 \mathrm{~min}$ & 4 \\
\hline
\end{tabular}

\section{Results of research}

Anaerobic power was stated in watts (W) according to the indicators of the digital monitor of Concept-2. Anaerobic power capacity test lasted for 30 seconds what actually is modified Vingeit test especially for the rowers of Murjani Sport Gymnasium. The test results were processed by the t-test Independent Samples test, as a result all values were similar $(\mathrm{p}<0.05)$, although a tendency towards different result was shown by the muscles latisimus dorsii $(\mathrm{Hz})$ left side $\mathrm{p}=0.065$, but the muscle triceps brachii $(\mathrm{mV})$ in the right side had $\mathrm{p}=0.056$ before the movement, but for the muscle latisimus dorsii during movement $(\mathrm{mV})$ it was $\mathrm{p}=0.086$. Other results had from $\mathrm{p}=0.123$ up to $\mathrm{p}=0.809$ (Table 2). 
Proceedings of the International Scientific Conference. Volume VI, May $22^{\text {th }}-23^{\text {th }}, 2020.115-122$

Table 2 T-test Independent Samples test p-values in the 1st anaerobic power capacitytest

\begin{tabular}{|l|c|c|c|c|}
\hline \multicolumn{1}{|c|}{ Muscle } & $\begin{array}{c}\text { Frequency Hz } \\
\text { before } \\
\text { beginning of } \\
\text { movement }\end{array}$ & $\begin{array}{c}\text { Frequency Hz } \\
\text { during } \\
\text { movement } \\
\text { execution }\end{array}$ & $\begin{array}{c}\text { Biopotential } \\
\text { mV before } \\
\text { beginning of } \\
\text { movement }\end{array}$ & $\begin{array}{c}\text { Biopotential } \\
\text { mV during } \mathrm{m} \\
\text { ovement } \\
\text { execution }\end{array}$ \\
\hline $\begin{array}{l}\text { Musculus } \\
\text { Triceps Brachii } \\
\text { (LSB) }\end{array}$ & 0.763 & 0.809 & 0.714 & 0.688 \\
\hline $\begin{array}{l}\text { Musculus } \\
\text { Latisimus } \\
\text { Dorsii (RSB) }\end{array}$ & 0.065 & 0.622 & $0.107^{*}$ & $0.103^{*}$ \\
\hline $\begin{array}{l}\text { Musculus } \\
\text { Triceps brachii } \\
\text { (LSB) }\end{array}$ & 0.298 & 0.361 & 0.555 & 0.751 \\
\hline $\begin{array}{l}\text { Musculus } \\
\text { Latisimus Dorsi } \\
\text { (RSB) }\end{array}$ & 0.256 & 0.123 & $0.0796^{*}$ & $0.091^{*}$ \\
\cline { 4 - 5 } & & \multirow{2}{*}{0.056} & 0.194 \\
\hline
\end{tabular}

$\left(^{*}\right)$ - percentage average $p$ - value

(LSB - left side of body, RSB - right side of body)

The means were stated for the rowers' results in each group which were processed with SPSS-17t-test. The results of anaerobic power capacity test of EG and CG prove that the groups are homogeneous, what is testified with t-test $\mathrm{p}=0,706$. When stating EMG in all cases both the muscle impulse frequency $\mathrm{Hz}$ and $\mathrm{mV}$ and biopotential percentage relation $(\mathrm{mV})$ were identical. Also in this test the results prove that both groups have shown equal results where $\mathrm{p}<0.05$. When stating the variation coefficient of EG and comparing the means, it was found out that the variation coefficient is $22.0 \%$, but the variation coefficient of CG is $18.1 \%$ what shows that the groups are not homogeneous.

To state muscle biopotential $(\mathrm{mV})$ and frequency $(\mathrm{Hz})$ of CG the first and the second test were analyzed, thus stating differences between the test results. Only in two cases t-test Paired differences were significant: for the muscle triceps brachii of the right side of the body before the beginning of the movement in frequency $(\mathrm{Hz})$ field $\mathrm{p}=0.039$ and also in amplitude $(\mathrm{mV})$ field during the execution of the movement 0.018 . However, taking a look at the percentage relation result differences it is concluded that the results of the muscles of the right side of the body are different, but the results of the muscles of the left side of the body are similar what is similar to the anaerobic power test of CG. But in the ANOVA test the differences were not recorded in none of the cases. Comparing to EG it is concluded that the muscle triceps brachii has improved the result, frequency $(\mathrm{Hz})$ and amplitude $(\mathrm{mV})$ have increased. 
Ciekurs et al., 2020. Local Vibration Influence of Electromyography Parameters on Anaerobic Capacity Test in Rowers

Table 3 The comparison of T-test Independent Samples Test p-values in anaerobic capacity 2nd test

\begin{tabular}{|l|c|c|c|c|}
\hline \multicolumn{1}{|c|}{ Muscle } & $\begin{array}{c}\text { Frequency Hz } \\
\text { before } \\
\text { beginning of } \\
\text { movement }\end{array}$ & $\begin{array}{c}\text { Frequency Hz } \\
\text { during } \\
\text { movement } \\
\text { execution }\end{array}$ & $\begin{array}{c}\text { Biopotential } \\
\text { mV before } \\
\text { beginning of } \\
\text { movement }\end{array}$ & $\begin{array}{c}\text { Biopotential } \\
\text { mV during } \\
\text { movement } \\
\text { execution }\end{array}$ \\
\hline $\begin{array}{l}\text { Musculus } \\
\text { triceps brachii } \\
\text { (LSB) }\end{array}$ & 0.015 & 0.040 & 0.044 & 0.099 \\
\hline $\begin{array}{l}\text { Musculus } \\
\text { latisimus dorsii } \\
\text { (LSB) }\end{array}$ & 0.570 & 0.042 & $0.861^{*}$ & $0.763^{*}$ \\
\hline $\begin{array}{l}\text { Musculus } \\
\text { triceps brachii } \\
\text { (RSB) }\end{array}$ & 0.041 & 0.166 & 0.536 & 0.008 \\
\hline $\begin{array}{l}\text { Musculus } \\
\text { latisimus dorsi } \\
\text { (RSB) }\end{array}$ & 0.210 & 0.559 & $0.878^{*}$ & $0.000^{*}$ \\
\cline { 4 - 5 } & & 0.204 & 0.426 \\
\hline
\end{tabular}

$\left(^{*}\right)$ - ANOVA test; $\left({ }^{* *}\right)$ - percentage average $p$ - value

(LSB - left side of body, RSB - right side of body)

Comparing the results of RG and CG with the t-test Independent (Table 3) it is concluded that $\mathrm{p}=0.006$ what shows difference in group results, as before the test $\mathrm{p}=0.706$ what shows the group homogeneity. Stating the results between the groups it was found out that the result differences of the muscle triceps brachii in the left side of the body are observed before the beginning of the movement in the muscle innervations amplitude $(\mathrm{mV}) \mathrm{p}=0.015$ and in amplitude $(\mathrm{mV}) \mathrm{p}=0.044$ but during the execution of the movement frequency $(\mathrm{Hz}) \mathrm{p}=0.099$ what shows a tendency for the muscle innervation amplitude $(\mathrm{mV})$ to differ. Taking a look at the muscle latisimus dorsii in the left side of the body it was concluded that the result is different during the execution of the movement where frequency $(\mathrm{Hz})$ $\mathrm{p}=0.042$ and amplitude $(\mathrm{mV}) \mathrm{p}=0.008$. Taking a look at the muscle triceps brachii in the right side of the body differences are observed only before the beginning of the movement in frequency $(\mathrm{Hz})$ field where $\mathrm{p}=0.041$, but for the muscle latisimus dorsi in the right side of the body during the execution of the movement the amplitude $(\mathrm{mV}) \mathrm{p}=0.039$, but in other cases the results are similar. Stating the differences of percentage relation of the mean results it was observed that only for the muscles latisimus dorsii of the left side of the body during the execution of the movement $\mathrm{p}=0.000$ what shows differences, but in other cases the results were stated similar.

Stating the results of EG second test of anaerobic power capacity it was necessary to analyze the dynamics of every test participant between the first and 
second test, thus stating in which second the highest result was reached and how long the highest result in watts (W) was maintained and in which second the result started to drop. Stating the participants' results in the anaerobic power capacity test there is the tendency for the result to increase and maintain longer than it was in the first test, respectively, the rowers work capacity to realize a greater load for longer time on the static rowing ergometer CONCEPT-2 has improved what confirms the positive effect of local vibration on anaerobic power.

\section{Discussion}

The obtained results unumbiguously testify the positive effect of LV on anaerobic power capacity, as well as the increace of electric activity $(\mathrm{mV})$ in the $m$. triceps brachii is proved what testifies the hypothesis, and the developed methodology allows further researchers to choose it as a basis for further research. A possibility to apply LV in practice according to the developed methodology which has been proved as an effective training means in rowers' preparation process in winter is offered to present and future coaches. During the development process of the Thesis sources of research literature are taken a look at and analysed what is essential in Sport Science in Latvia and for sport coaches who with the help of LV would like to improve their trainees' work capacity.

Many scientists in their researches have used different vibration frequencies, amplitude and time of vibration to determine the immediate and short term effect (Souron, Besson, Millet, \& Lapole, 2017). The result analysis of the carried out research shows that the hypothesis forwarded for this research has proved to be true as stating the MSG rowers' results in anaerobic power test it is concluded that for the EG rowers the ability of maximal anaerobic power have significantly improved, proved by the results of the t-test and ANOVA analysis. The results of the CG rowers have also improved, however, having processed the obtained data using the t-test and ANOVA analysis it was stated that the results are similar, but significantly different (lower) in comparison with the dynamics of the EG rowers' results. Thus the positive effect of the local vibration on athletes' anaerobic power ability is proved. LV is effective and applicable in the training process in the strength development stage in winter - preparation period.

\section{Conclusions}

In the anaerobic power capacity test of EG rowers and CG rowers using the one factor dispersion analysis ANOVA the credibility of EG rowers' results is significant ( $p=0.000)$, the credibility of CG rowers' results is not proved ( $p=0.473$ ). the obtained data in the second test testify that the result of EG rowers has increased significantly. Stating the muscle biopotential $(\mathrm{mV})$ and innervation 
Ciekurs et al., 2020. Local Vibration Influence of Electromyography Parameters on Anaerobic

Capacity Test in Rowers

frequency $(\mathrm{Hz})$ it is concluded that the muscles triceps brachii in the right and left side show the result differences in the t-tests, as well as in ANOVA. Comparing EG and CG some result differences of the muscles triceps brachii un latissimus dorsi $\mathrm{p}>0.05$ were observed.

\section{References}

Hawkins, D. (2000). A new instrumentation system of training rowers. Journal of biomechanics, 33(2), 241-245.

Knipše, G., Čupriks, L., Ciematnieks, U., Čuprika, A., \& Leščinskis, M. (2009). Vēdera muskulatūras elektromiogrāfiskāa aktivitāte fizisko vingrinājumu laikā. Latvijas universitātes raksti - medicīna, 750, 245. - 252.

Nowicky, A.V., Burdett, R., \& Horne, S. (2005). The impact of ergometer design on hip and trunk muscle activity patterns in elite reowers: an elektromyographic assesment. Journal of sports science and Medicine, 4, 18-28.

de Paula, L.V., Moreira, P.V.S., \& Szmuchrowski, L.A. (2016). Acute effects of local vibration on the neuromuscular responses. Bioscience Journal, 32(6).

Schaar, H., \& Mattes, K. (2010). Comparison of the electromiographic activity patterns of elite rowers on the rowing ergometer and the Dyno. University of Hamburg, Germany, department of human movement.

Siegmund, L.A., Barklty, J.E., Knapp, D., \& Peer, K. (2014). Acute effect of local vibration eith biomechanical muscle stimulation on low-back flexibility and perceived stifness. Athletic training and sports health care, 6(1), 37-45.

Souron, R., Besson, T., Lapole, T., \& Millet, G.,Y. (2018). Neural adaptation in quadriceps muscle after 4 weeks of local vibration training in young versus older subjects. Applied physiology, nutrition, and metabolism, 43(5), 427-436.

Souron, R., Besson, T., Millet, G.Y., \& Lapole, T. (2017). Acute and chronic neuromuscular adaptations to local vibration training. European journal of applied physiology, 117(10), 1939-1964.

Souron, R., Zambelli, A., Espeit, L., Besson, T., Cohrane, D.J., \& Lapole, T. (2019). Active versus local vibration warm-up effects on knee extensors stiffness and neuromuscular performance of healthy young males. Journal of science and medicine in sport, 22(2), 206-211. 